\title{
Political Marketing Application By Political Parties: A Framework For Understanding Its Impact In Democracy
}

\author{
Klajdi Mone, Ph.D candidate
}

Faculty of Human Sciences,

University of Vlora "Ismail Qemali", Albania

Ass. Prof. Evelina Bazini

Faculty of Economy,

University of Vlora "Ismail Qemali", Albania

\section{Doi:10.5901/mjss.2013.v4n4p399}

\begin{abstract}
Marketing is becoming an important tool in politics in general, it provides core benefits that align with the conditions necessary for democracy. Marketers provide consumers with information so that they can make better choice. They see tremendous values in active customer engagement as it allows them to learn about their customer's needs and preferences, knowledge that can be applied to marketing strategies and communications.Democracies involve "enlightened" citizens participating in the political process and making their choices from among the available candidates. The aim of this article is to present an overview on the functions of political marketing trying to explains how the functions of political marketing are effectively applied by political parties and how political marketing effect democracy in creating public opinion in favor of the party.
\end{abstract}

Key words : political marketing, political parties, democracy

\section{Definition and origin of political marketing}

Marketing is not a term that historically we associate with politics. A recent textbook definition of marketing speaks in terms of "understanding, creating, communicating, and delivering customer value and satisfaction... at a profit" (Kotler \& Armstrong, 2001, p. 5). Politics is normally associated with ideas and ideologies. Political parties relied on a body of core ideas that were subscribed to by a significant number of members of the electorate, that were employed to demarcate themselves from their opponents and to gain support from their electorate. The real battle was waged for the votes of the undecided, those without ideological predilections, but the normative view is that this battle did not involve marketing; politics was about selling and salesmanship and the only aspects of marketing involved related to its promotional tools (O'Shaughnessy, 1990; 2001; Wring, 2002). The increasingly non-partisan sections of the electorate, it has been argued, seek to make connections to parties; through the information they receive they attempt to find the party or candidate that most closely matches their personal ideas and values (Popkin,1994), an observation that has led to an increased prioritization and professionalization of political communication (Negrine \& Lilleker, 2002). Depending on how and where they seek this information, and often also on how digestible and relevant that information is, they find one party or candidate more acceptable than another. Some argue this is calculated by reference to a virtual profit and loss account, with voters asking which party offers the most advantages for me personally (Heath et al, 2000). It is the process by which they make this decision that is important when we think about the way modern political parties act and the way in which marketing has become a commonplace feature of the modern political campaign (Lillekert \& Negrine, 2004).

The idea of Political marketing originated with the broadening "debate" of Marketing in the 1970's by Scholars such as Kotler and Levy (1969), Kotler and Zaltman (1971), Kotler (1972), Hunt (1976) and Levy (2002). This made marketing research possible in non-profit entity. The concept of marketing therefore is no longer restricted to the domain of exchange of goods and services alone but the distribution of ideas. The literature on political marketing further experienced increase growth in the 1990's by the work of scholars such as Newman (1994, 1999a, b), Maarek (1995), Lees-Marshment (2001), O'Shaughnessy and Henneberg (2002), Wring (2005) and Ormrod (2004). These scholars offer different definitions of political marketing but resolved that, it is the application of marketing principle to politics (Stromback et al., 2010). The literature on political marketing has made possible study of political parties and its 
relationship to their target groups and other Stakeholders (Stromback et al., 2010). This lead to the understanding of what are the demands of the electorate, how do political parties respond to these demands and satisfy them. In politics it is assumed that there is a political market, where aspirants seek the electorate's support (Votes) in order to win an election. The various means through which an aspirant seeks the voter's support therefore is political marketing. Harrop (1990) argued in support of this by describing political marketing as not just being political advertising, party political broadcast and electoral speeches but covering the whole area of party positioning in the electoral market. O'Cass (1996) uses an exchange model to further conceptualize political marketing. He explained that when voters cast votes, there is transaction taking place. The party in return for these votes offers better government and policies after election. Scammell (1995) proposed that the application of marketing concept in politics may result in politics becoming more democratic. Thus, bringing about improvement in the quantity and quality of information flows from the electorate to parties and candidate, making them more sensitive and responsive to voters' needs. This improves the channels of communication from politicians to the electorate and even to every specific segment of voters (Kolovos and Haris, 2005; Scammell, 1995) ${ }^{1}$.

\section{Definition of Political Parties}

History has shown that in its beginnings there were no real political parties, but only groups with opposing interests. Over the years the parties were consolidated as groups of individuals with the same views and convictions intended to influence the power and governance. The political parties are an essential element of political life. The political parties are not phenomena that have emerged in the modern era. There are authors who argue that political groups, although they have not had the nowadays organized form of political parties, there have been such since the ancient times, particularly in Greece and Rome. The political wars between supporters of the agricultural current and that of trade are mentioned in Greece. In Rome are popular the political wars among the supporters of Grake brothers and their enemies, as well as between Caesar and Pompey etc. At the time of feudalism are to be marked the political wars in Italy between the partisans of the papacy and the Emperor. Also it is mentioned the birth of two traditional English parties, Vige and Tore in the XVII century or the emergence of political clubs in France before and during the French Revolution in the XVIII century (Omari, L. 2004).

In the classical liberal period they have been treated as parliamentary groups such as: "The Right " or "The Left", deprived of a real stability in the country. Later this era was accompanied by the expansion of voting and transformation of political parties from organizing groups to real measures parties. The latter are characteristic of modern states. All this brought about the necessity of constitutional recognition of political parties as an important social formation which occurred for the first time in Italy with the Constitution of the Second World War (Omari, L. \& Anastasi, A. 2008).

Most authors tried to give definitions of political parties excluding such elements as, plurality of persons, organization, purpose, ideology, content etc. The French constitutionalist Benjamin Constant political party defined the political party as "a group of people who adhere to the same political doctrine." In the Albanian law on political parties is provided that: "The political parties are voluntary unions of citizens on the basis of ideas, opinions or beliefs or of the common political interests, who seek to influence the life of the country through the participation in elections and representation of people in the elected organs of power".

The historical sources speak of the existence of different political parties in Albania, in the Albanian lands outside the boundary of today and in the Diaspora since the early 20-th century (Krasniqi A, 2006). So in the early 1900 the two parties are established in Elbasan that are People's Party and that of the Bejlere, while in Shkodra was created a proItalian party. The political parties were not only established within the territory of Albania, but also in the Albanian Diaspora in the world: for instance in the U.S. was created the Autonomist Party, in Skopje was established the party of Hoxha.

\section{The founders of political parties}

The first works about political parties in the world have been published around the end of the XIX century and in the early XX century. These works were dedicated to the three founding fathers of political parties, Moisei Ostrogorski, Roberto Michels and Max Weber.

\footnotetext{
${ }^{1}$ According to the definition of product given at Principles of Marketing, 11th edition, by Kotler and Armstron 2006, product include physical objects, services, events, persons, places, organizations, ideas or mixes of these entities. The author is trying to explain the importance of marketing applied by political parties to achieve their goals and objectives. 
Ostrogorski as a social reformer was for the creation of modern reformed political parties, which had a crucial role in policy (Brechon, P. 1999).

Supporter of a liberal philosophy, he was against criticism that defined the parties as mechanisms of political conflicts or as organizations with military discipline. He called for a reform to replace the existing parties "omnibus" with "ad hoc" party. The first is called "omnibus" because the parties while offering a program of action for all issues of political debate, can not be other than mechanical and solid. In contrast an "ad hoc" party which just requires engaging in a specific matter until it is resolved, would be much less compelling for supporters who would be able to attend some parties under the principles they advocate.

This type of organization would create more passive people who would vote for candidates that would yield the best alternatives to solve fundamental problems for them. The proposal may seem naive in the eyes of an actual political scientist who says that all political groups tend to expand their programs of action. He also says that simplification of the debate is a condition of political action and the articulation of the requirements set by pressure groups is a difficult feature to be accepted by the governors without the mediation of political parties.

Roberto Michels another founder of political parties devoted their creation to the distinguished ancestors, Mosca and Pareto (Brechon, P. 1999). He was inspired by the elite theories protected by them. He published in 1911 in Germany a paper about the oligarchic tendencies of political parties, based on a sociological analysis of the functioning of the German social-democracy. Created to be instruments of competitive democracies, parties are inevitably a place of derivative oligarchy. He stated that the changes of competitive democracies lead to centralization and bureaucratization of the party, which should be able to take quick decisions.

Max Weber is often regarded as one of the pioneers of political parties approach with the element politics (Brechon, P. 1999).

We should remind of his insistence on the professionalization of politics in the modern era. Politics became for a large group of people a major activity. According to him the parties are defined as organizations with free participation requiring the participation of their leaders in power and allowing militants to defend a case or benefit because of their loyalty to the leader. So the parties were developed in the XIX century in a rational and legal way, more organized and bureaucratized under certain precise rules. But the dominance of major policy is competed more and more by the modern organization of the political parties that have turned into merely true machines.

\section{Political marketing functions}

\subsection{Product function}

In Political Marketing practice, a product, like mainstream marketing, should be formally designed to be offered by a political party to her electoral market. The product, can be intangible like a promise of good governance, the image of the candidate, an ideology or certain foreign policies, etc. (Menon, 2008). The major conditions for an exchange (or exchange related interaction) are the subsistence of an offering that is valued by the buyer (voter or citizen), produced by the seller (political party or candidate) and willingness of the both parties, the seller and the buyer, on the exchange for mutual benefits. Candidate's characteristics play a decisive role in voter's decision making process (Sniderman, 1991; Popkin, 1994). The product function constitutes main elements of provision of an offering and is a strategic management of a trade off process among elements of leading or following, voters preferences, balancing the inflexible (e.g. ideology), the flexible (i.e. political agenda) and the semi flexible elements (e.g. certain characteristics of candidate) (Henneberg, 2003). Product function does not provide much more than a promise to be delivered in the future under uncertain circumstances through distribution. However this promise has characteristics of "public goods", i.e. it is promised to and will be "consumed" by every one - not just target segment (Wortman, 1989) ${ }^{2}$.

\subsection{Distribution Function}

According to Henneberg, Understanding of Political Management (2002) distribution function refers to the product availability to the target market and has two aspects, campaign delivery and offering delivery. Through campaign delivery function the primary exchange partner, the voter, is provided access to all relevant information about the political

${ }^{2}$ According to the marketing viewpoint consumers (voters) pay the price (give their vote) of the product (political party or candidate of a political party) and in turn take the product which they use ore consume. In the case of political parties consumers take promises which will be fulfill during the parity's or candidate political mandate. 
products, information regarding key party policies and programs are disseminated, placing the candidates in right channels, and making sure that channel of distribution fits the ideology of the party etc. (Sniderman, 1991; Popkin, 1994). The complexity of campaign delivery function is expected to increase with the introduction of new media like ecampaigning and web TV. The offering delivery aspect refers to the "fulfillment" of political promises made by the party or candidate (Harrop, 1990; Palmer, 2002). This aspect comes into play when a political party or candidate has the political and legal resources to fulfill their promises, i.e. when they are in governing position. As services are 'co-created' i.e. the electorate and the executives are inscribing and enacting policies together in a participatory and coordinating fashion; monitoring of offering delivery is crucial for the success of distribution function of political for the success of distribution function of political marketing campaign (Wortman, 1989).

\subsection{Cost function}

One of the elements of mainstream marketing is to sell and make a product available at a price which provides greater monitory utility to the target audience compared to other products available in the market (Wortman, 1989). In Political Marketing, cost function deals with the management of attitudinal and behavioral constraints of constituency members through carefully designed campaign strategies. All the information regarding the political products should be available to the voters without spending a penny (Henneberg, Understanding of Political Management, 2002). Niffeneager (1989) developed the concept that voters pay perceived prices as psychological construct, i.e. feelings of national, economic and psychological hope or insecurity. Another role of cost function is to minimize the opportunity cost in decision making process and electoral act itself.

\subsection{Communication function}

Communication function in Political Marketing deals with communicating the internal (party members) as well as external (voters) stake holders about the offer and its availability (Harrop, 1990; O' Cass, Political Marketing, 2001; Harris P. , 2001), the purpose is to inform, remind or persuade (Kotler \& Kotler, 1999). According to Scamell (1995), importance of communication is just like heart in human body. According to Wortman 1989 and Harris 2001, for a political party communication deals with interpretation of complex political jargons, spreading of political ideas, contents of political campaign, future programs and simplification of political messages. It interacts with campaign delivery aspects of distribution function, prescribes a dialogue and provides a medium for exchange partners.

\subsection{News management function}

Public Relations Management plays indispensable role in the success of a Political Marketing Campaign and is aimed at managing building positive attitude of the public and media groups (secondary exchange partners) through managing good news by establishing good long term relationship with them. It is a not a paid activity and could not be directly controlled by the candidate and political organization. Most of the political discourses with the electorate are mediated through independent third parties e.g. media people. Managing good relationships with third parties contributes great importance in building good image of the candidate and political party (Wring, 2002). News management involves utilization of distribution channels with inherently high credibility levels. However, the communication could not be controlled; it can only be influenced for its better management. The exchange partners of the news management are mostly journalists and opinion leaders (Henneberg, Understanding of Political Management, 2002; Frankline, 1994).

\subsection{Funds raising function}

Unlike mainstream marketing fund raising is an important issue in Political Marketing. This function deals with collection of funds for political activities, the performance of other functions also depends on availability of funds. For the success of the political actors, availability of sufficient funds is vital which calls for a distinct fund raising function (Menon, 2008). Political parties, to a varying extent, depend on membership fee, donations, etc. for funds.

\subsection{Parallel management function}

This function focuses on the co-ordination of campaign activities of the political party with those organizations who have overlapping or similar point(s) on their agenda, like "Green Peace" idea, which overlaps among many European social 
and democratic organizations (Henneberg, Generic Functions of Political Marketing Management, 2003). Endorsement of parallel activities by other organizations increases the trustworthiness of campaign message. Furthermore, coordination and synergy in managerial activities could make the use of campaign resources more efficient. Campaign coordination in the political sphere must be seen as a generic function because of possible network effects of working together with other relevant actors in the political market (Menon, 2008).

\subsection{Internal cohesion management function}

This function deals with managing the relationship among party members, activists and spokes persons. This function plays a very vital role in creating internal stability, credibility and party's outside image, and should be managed professionally because it has strong repercussions on the voters' assessment of candidate and/or his party (Henneberg, Generic Functions of Political Marketing Management, 2003). However a too 'monolithic' appearance of the party gives the impression of an undemocratic decision making process and derisory influence of grass root members within the party. As much as one can exercise power over others by satisfying their needs and expectations; one thereby paradoxically submits oneself to their pioneer (Panebianco, 1988).

\section{Conclusions}

Democracy is the government of the people by the people and for the people. Ogunleye (2005) argued that democracy is people initiated, people promoted, sustained by the people for the benefit of the people. The people only cannot democratize without these anchoring factors such as the constitution, respect for rule of law, strong institutions, independent electoral system, education, security end a buoyant economy.

Marketing according to Kotler (2001) involved not only goods and services, but also entities like experiences, events, persons, places, properties, organizations, information and ideas. This implied that for a customer to be satisfied and possibly be identifying with a particular brand of a product, the value chain must go beyond the product. It is therefore pertinent that in political marketing, these understand must be well enshrined and accepted. In order to create and establish cordiality in political arena that would engender democratic sustainability, these holistic marketing orientation must come to play.

Nowadays political parties have adopted far more sophisticated techniques of political marketing, and the news media have diversified in channels and levels. Good marketing delivers benefits that are very similar to the pillars of democracy: marketers give consumers information; they offer choice; they engage consumers; most seek to be inclusive; there is fair, mutual exchange with consumers; and subsequent consumption of goods and service satisfies needs and improves human welfare. The media are supplying the political information that voters base their decisions on. They identify problems in our society and serve as a medium for deliberation.

Political marketing provides extra assistance to the effectiveness of the message, every citizen has the chance to get involved with the political affairs, develop critical thinking, encourage debate, this helps democracy by increasing the number of information sources and the amount of information available to voters

We should not forget that democracy is more than elections, while presenting this framework for the impact of political marketing in enhancing democracy, we have to keep in mind that the relationship between democracy and market is shaped by numerous factors, and requires a more sophisticated type of comparative study involving a serious empirical component.

\section{References}

R.A. Gbadeyan. 2001. Political Marketing Strategies and Democracy in Nigeria. Asian Journal of Business Management 3(1): 8-17, 2011, ISSN: 2041-8752, @ Maxwell Scientific Organization, 2011

Olotu, O. A. \& Ogunro V. O. 2013. Political Marketing: An Effective Strategy for Quality Leadership and Sustainable Democracy in Nigeria. International Journal of Marketing Studies; Vol. 5, No. 1; 2013, ISSN 1918-719X E-ISSN 1918-7203, Published by Canadian Center of Science and Education

Lilleker D.G., \& Negrine R. Mapping a market-orientation: can we only detect political marketing through the lens of hindsight? [Online Available]

Kavanagh D. Party democracy and political marketing: No place for amateurs? [Online Available]

Nazar, M. S., Latif, A. Scope of Political Marketing in the Context of Pakistani Political Environment. [Online Available] 
http://www.google.com/search?q=Scope+of+Political+Marketing+in+the+Context+of+Pakistani+Political+Environment\&og=Scope+of+Po litical+Marketing+in+the+Context+of+Pakistani+Political+Environment\&sourceid=chrome\&ie=UTF-8

Menon, Sudha Venu. 2008. Political Marketing: A Conceptual framework. ICFAl Business School, Ahmedabad. [Online Available] athttp://mpra.ub.uni-muenchen.de/12547/ MPRA Paper No. 12547, posted 06. January 2009 / 10:16.

Brechon, P. 1999. Les partis politiques. Juillet, pg. 9

Krasniqi, A. 2006. The Albanian parties in Albania. Tirana, pg. 28.

Brechon, P. 1999. Les partis politiques, Juillet, pg. 7-8

Omari, L. 2004. Principles and institutions of the public law, Tirana, pg. 155

Omari, L. \& Anastasi, A. 2008. Constitutional law, Tirana, pg. 175.

Kotler, P., \& Kotler, N. (1999). Political Marketing. In B. I. Newman, Handbook of Political Marketing (pp. 3-18). Sage, Thousand Oaks. 